\title{
Usability and the emotional relationships in collective buying sites: a case study
}

\author{
J. E. Silveira ${ }^{*}$ T. P. Anjos and L. A. Gontijo \\ Postgraduate Program in Production Engineering, Federal University of Santa Catarina, Technology Center, \\ Florianópolis, SC, BRAZIL
}

\begin{abstract}
Several people buy products that they will never use or even know what for. Feelings associated with pleasure, spontaneity and possession of something are reasons why people buy products without considering if they really need it or not if it will be useful or not, etc.. The collective buying sites are going up and offer products and services with great discounts. This study aims to relate the emotional design and usability concerning to collective buying sites and identify the reasons that influence people when it comes to buy something online.
\end{abstract}

Keywords: user experience; interface analysis; simplification of purchasing processes

\section{Introduction}

People often associate a product or service with their own identity, the presentation of the ego to another person. In a way, a product or service fulfills the role of understanding the ego, and is an instrument of pleasure, cult of fantasy and of novelty. According to Miranda [8],

"People express their ego on consumption and see the possessions, therefore, as part or extension of their own ego. This capacity for symbolization, in other words, to promote the union of an object (significant) and the message attributed to him (meaning), allows the adaptation of man to reality by means of abstractions of the elements that make up the world".

This leads us to the tendency to see possessions as symbols of the ego, so there is a strong association between the ego and possessions, which leads to the belief that a person's possessions are part of what this person are.

An object is to its users a form of expression, an instrument of dialogue. This dialogue is first built when the person chooses a product or service and this is in accordance with the intent of what the person wants to appear, subsequently exposes to others hoping the object be understood and interpreted, i.e., decoded by the others in same way it was coded in the choice of object.

People seek in consumption more than aesthetics, substantially its concept and its identity. People consume symbols, and more important currently are their meanings. "As humans, we are meaning machines, because people attribute meaning to everything. We live to mean, to make sense "[8].

\subsection{Method}

The present study can be considered exploratory. For Malhotra [7], exploratory research has as main purpose to explore a particular problem or situation to provide appropriate criteria and an understanding for the researcher. These methods are guided by the discovery of ideas and data and are characterized by versatility and flexibility. According to Gil [4], the exploratory study's main objective is to clarify, develop and change concepts and ideas seeking more precise formulation of problems that will be developed in subsequent researches.

\footnotetext{
* Corresponding author. Julia Elpo Silveira. Postgraduate Program in Production Engineering, Federal University of Santa Catarina, Technology Center, University Campus, Trindade, Florianópolis, SC, Brazil. PO Box 476, CEP 88040-900. Tel.: +55 48 8466-0998. E-mail: juelpo@gmail.com.
} 
For the survey, a questionnaire was developed based on the model of the Questionnaire for User Interface Satisfaction (QUIS), and applied according to the defined market segmentation [6].

\section{Usability}

Usability is the ability that a product or service must offer its users, in a specific context of use, the achievement of tasks and specific goals with effectiveness, efficiency and satisfaction [9]. The effectiveness is the "accuracy and completeness with which users achieve specific goals". Efficiency refers to the "resources expended in relation to accuracy and completeness with which users achieve goals". Yet, the satisfaction refers to "lack of discomfort and presence of positive attitudes with the use of a product".

Santos and Maia [13], quotes that satisfaction is related to user expectations regarding an interface. Depending on how this interaction occurred, the result is reflected in their attitude. A negative level of satisfaction is probably the greatest single factor that influences the decision to continue or not to use a particular application, website, etc.

Too often, the usability is the only ergonomic criteria recognized by the designers to be considered in creating a human-computer interface. It is a measure or an estimate of the likely performance of the users [1].

Usability is the quality of the system that makes it easy to learn, easy to use, easy to remember, error tolerant and be pleasant to use. The usability problems in software can be observed that any feature can delay, hinder or impair the accomplishment of a task, embarrassing or annoying the user [2].

\section{Emotional design}

Emotions change perceptions, behavior and the parameters of thought. According to Norman [10], emotions are inseparable from cognition, as part of a system for formulation of value judgments, which constantly affect our behavior, thinking, our decisions and the way we interact with each other.

Reflecting on Norman's visions about emotions to the design field, it may say that the emotional design is divided into three levels: visceral, behavioral and reflective. Visceral design regards only the appearance of the product or service; behavioral design is bound to pleasure and effectiveness at the time of usage; and reflective design considers the memories, personal satisfaction and self-image of the individual related to the product or service. Emotions are based through the memories that products or services evokes or the experiences they offer, and we can say which the attraction leads us to make decisions.

In emotional design it is approached that attractive objects work better, where a product or service must meet the three levels of the design described above, being that the three levels interact and can offer a range of user experiences.

Norman [10] says that although the cognitive analysis of usability and function is important, the affective analysis is also because good design is increasingly based on the needs of users, i.e., understanding the use, ease of implementation of tasks, and to offer pleasure and satisfaction in the interaction. The cognitive aspects of design by usability, aesthetics or practicality are associated with the emotional aspects. Emotion and cognition are integrated when making a choice, considering that man does not choose objects just by form or function, but also the meaning that the object provides.

\section{Collective buying sites and emotional design}

The collective buying sites are going up and offer products and services with great discounts. According to IBOPE [5], were sites of its kind had, in August 2010, 3.6 million visits. In February and March 2011 the number of Internet users who use these sites increased from 13 million to 17.1 million [15]. The $30 \%$ increase from one month to another is impressive, especially when comparing the number of Internet users in the country, users of collective buying sites have represent $40 \%$ of the total.

The collective buying sites have emerged as a new method of shopping. According to Pereira [12], held to Ibope Media research and identified consumer profiles Brazilian e-commerce. The survey of 2,500 Internet users in Brazil pointed out that the buyer electronic focuses primarily on Class A and B, are highly educated and spends an average of R $\$ 118.00$ per month. Although women have fame of "spendthrift," the majority buying in these channels are men, accounting for $54 \%$. Considering this potential market, the first collective buying site totally Brazilian was Fish Urban in 2010.

These sites work as follows: an offer, whether it be products or services is placed on the site for a limited 
time. Anyone who is registered on the site can make a purchase and print a coupon, which have an expiration date and requirements for use. This coupon entitles you to discounts, but it must be presented at some establishment to make the exchange the coupon for the product or service.

\subsection{Explanation to the success}

The success of collective buying sites has an explanation, according to Serra [14], is based on practices of web design and emotional design associated with neuroscience, the science of physiological processes in the brain to understand the reasons of human behavior and identify areas of the brain respond to certain stimuli.

One of the conclusions most relevant given by scientists is that we have three brains (Figure 1):

- Ancient Brain: is the most primitive and is concerned about safety and is determining all the time what is dangerous. He is also responsible for the basic and involuntary functions, such as digestion and breathing.

- Intermediate Brain: it is responsible for emotions and is the source of many impulse buys.

- New Brain: it is the most recent structure and does the processing of language, reading, thinking and planning. Use sentence case in the title and headings.

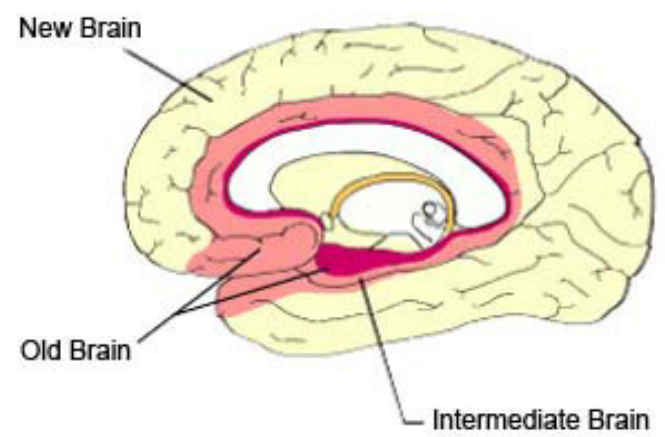

Fig. 1 - The three brains. Source: Weinschenk [16].

According to studies, the old and intermediate brains are related to the unconscious and the impulse and are worried about survival and procreation, the basic needs of all animals. Therefore, anything that attracts these two instincts, such as food, sex and danger, for example, humans will pay more attention. But the new brain uses logic and reason to explain human behavior. This brain has to think that is in control and to attract it is necessary subtlety. So having a well identifiable layout with large buttons, attractive images, seductive texts and, especially, good discounts, awakens in man the desire to click and buy [14].

The elements for classification within the proposed of Weinschenk [16], corresponding to nine factors:

- Social Validation: awakens the primitive needs. The need for inclusion in the group, do what others are doing, listen to the views of others and repeat successful experiences of others are elements that can be achieved by using the user opinion, and witnesses, etc.

- Reciprocity and concession: emotional appeal. Ask for things in exchange for gifts is one way to make the person engage, hit on the intermediate brain. Promotions such as discounts, free shipping, as well as knowledge, reputation, and awards, make this element be reached.

- Shortage and Urgency: primitive instincts. The sense of urgency of time limitation to buy refers to the notion of danger, and that if something is scarce and difficult to access, it is assumed that is valuable and the human being tends to want it even more.

- Choices: emotional appeal. Human beings have difficulty making a choice when there are many options available, just offering a few distinct choices (restaurants, beauty, tourism, etc.) avoids confusing the client. It also attracts people with different interests.

- Survival: primitive instincts. The old brain is looking for changes in the environment or something that is important for the survival or maintenance of the species. Images related to sex, food or danger calls more attention to people.

- Commitment: emotional appeal. When the human being says something verbally or in writing, tends to compromise with what was said and tends to keep his word. Therefore, testimony, research and reviews are important because users are more committed to what they leave registered.

- Recognition: emotional appeal. The user tends to trust, and consequently buy, in people who identify themselves or finds attractive. Using images of people who have to do with the audience and "speak the language" of the user are elements that help to achieve recognition.

- Loss: emotional appeal. The human being is programmed to pay attention to situations that 
can make him lose something or to put him in danger. Fear of losing motivates more than the opportunity to win and he remembers more of things that had some emotional relationship, both positive and negative.

- Images and stories: emotional appeal. Stories and images hold more people's attention, besides that images are easier to remember than words. In addition, people pay more attention to texts when they tell a story, rather than simply list the advantages and disadvantages of a product or service.

\section{Collective buying sites: case study}

The aim of this study was to relate the emotional design and usability concerning to collective buying sites and identify the reasons that influence people when it comes to buy something online.

Initially a satisfaction questionnaire was developed based on the Questionnaire for User Interface Satisfaction (QUIS). In order to its implementation it was opted for market segmentation to define the target audience [6], where it was identified that people are aged between 18 and 49, pertaining to social classes $\mathrm{A} 1, \mathrm{~A} 2$ and B1 - classification according to ABEP [3] - focusing on the class A2. Therefore are people with average income level of $\mathrm{R} \$ 6,000$ (family income). They are residing in Brazil and potential users of collective buying sites. This consumer has the price as an important factor, but far from being the decisive factor when buying, this client actually focuses on the cost-benefit provided by the product or service.

Forty-seven responses were obtained and from this an usability assessment was made of the three most commonly used collective buying sites. It also were identified some characteristics related to usability and emotional design, which influence people to buy for this type of Website and why people prefer one website and not another.

\section{Results}

Of the interviewed, $62 \%$ are female and $77 \%$ possess 18 to 24 years, being that $77 \%$ said they often buy at shopping sites collectively. As regards the user's perception about the usability of the sites, 9\% find it difficult to find/navigate into sites, $13 \%$ have difficulty in locating new discounts and $11 \%$ did not think the sites are friendly. The collective buying site which the most users utilize is the Peixe Urbano with $90 \%$ of users, followed by Groupon with $69 \%$ and Clickon with $36 \%$.

The main reasons stated by the $23 \%$ who do not utilize collective buying sites are the lack of habit, lack of confidence in buying online, unaware of the advantages this type of service offers and deals that are not pleasing.

Using the Likert scale, $74 \%$ said that the discount/ final price influences a lot to purchase (Figure 2). $43 \%$ said that the number of people that already bought the offer didn't influence (Figure 3 ). $34 \%$ said that to know the company providing the service/ product influences a lot to buy the offer (Figure 4) and 34\% also said that the description of the product/service offered by the site influences a lot before buying (Figure 5).

\section{Discount/Final price}

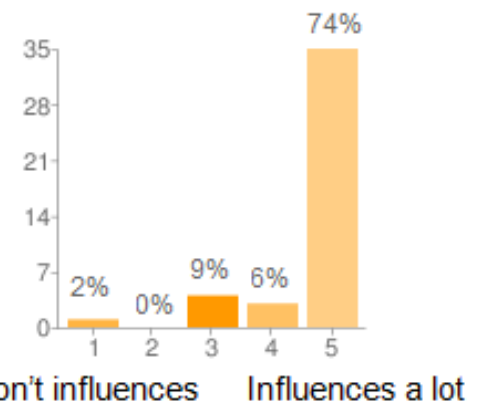

Fig. 2 - Influence of discounts on online purchases.

\section{Number of people that already bought the offer}

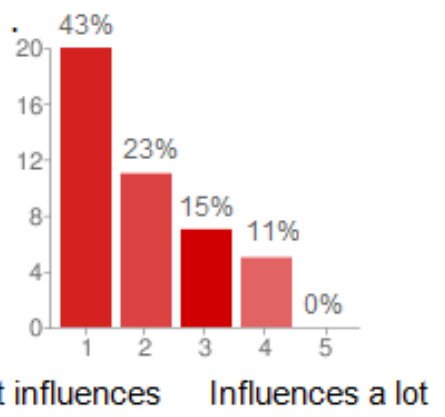

Fig. 3 - Influence of buyers on online purchases. 
The company that offer the product/service

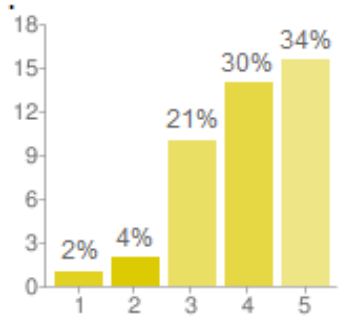

Don't influences Influences a lot

Fig. 4 - Influence of the company's name on online purchases.

\section{Description of the product/service}

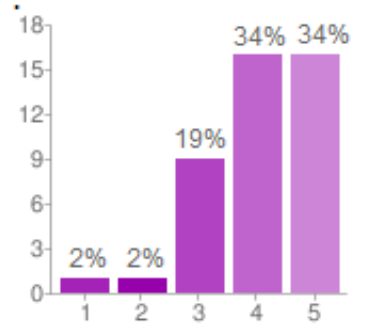

\section{Don't influences Influences a lot}

Fig. 5 - Influence of the description of product or service on online purchases.

\section{Discussion}

Usability and emotional design contributes to that the user in addition to accomplish tasks with effectiveness, efficiency and satisfaction, can also be persuaded to the time of purchase through the experiences that offer products or services.

However when this not occurs, it indicates that the usability and the three levels of emotional design have not been well developed or are not interacting with each other, as it $9 \%$ of users find difficult to navigate through collective buying sites, $13 \%$ can't find new promotions and $11 \%$ didn't think the sites are friendly. What needs to be reviewed so that user can have more pleasurable experience in the purchase act, is the improvement of strategic approach with the promotion and simplification of purchasing processes. By increasing simplicity, the usability increases too [11].

\section{References}

[1] T. P. Anjos, L. A. Gontijo and M. Matias, Comparação do desempenho dos usuários pelo tempo de uso no sistema e pelos tipos de problemas de usabilidade encontrados, in: $11^{\circ}$ Congresso Internacional de Ergonomia e Usabilidade de Interfaces Humano-Computador, USIHC, Manaus, Amazonas, 2011.

[2] T. P. Anjos and E. A. D. Merino, Design centrado no usuário: identificação do comportamento de tipos diferentes de usuários por meio de indicadores quantitativos, in: Congresso Brasileiro de Ergonomia, ABERGO, Rio de Janeiro, 2010.

[3] Brazilian Association of Research Companies (ABEP), Available at: <www.abep.org.br>, Access: April 20, 2011.

[4] C. Gil, Métodos e técnicas de pesquisa social, 5. ed., São Paulo: Atlas, 1999.

[5] Brazilian Institute of Public Opinion and Statistics (IBOPE), Compras coletivas crescem na internet, Available at: <www.ibope.com.br>, Access: July 29, 2011.

[6] P. Kotler, Administração de Marketing: a edição do novo milênio, São Paulo: Prentice Hall, 2000.

[7] N. K. Malhotra, Pesquisa de marketing: uma orientação aplicada, Porto Alegre: Bookman, 2001.

[8] P. Miranda, Consumo de Moda: a relação pessoa-objeto, São Paulo: Estação das Letras e Cores, 2008.

[9] NBR ISO 9241-11, Requisitos ergonômicos para trabalho de escritórios com computadores, Parte 11- Orientações sobre usabilidade, Brasil: ABNT, 2002.

[10] D. A. Norman, Design Emocional: por que adoramos (ou detestamos) os objetos do dia-a-dia, Rio de Janeiro: Rocco, 2008.

[11] D. A. Norman, Living with Complexity, Cambridge: The MIT Press, 2011.

[12] C. Pereira, Revista Marketing, Editora Referência: Janeiro, 2011.

[13] R. Santos and F. Maia, A importância da usabilidade de interfaces para a qualidade do aprendizado mediado pelo computador, in: 5th International Congress of Ergonomics and Usability, PUC-Rio, Rio de Janeiro (RJ), 2005.

[14] R. Serra, Por que os sites de compra coletiva fisgam você: especialistas analisam design de sites a partir da neurociência, Administradores: o portal da administração, Access: February 11, 2011.

[15] UOL Economia, Número de internautas nos sites de compra coletivas cresce $30 \%$ em março, Available at: $<$ http://economia.uol.com.br/ultimasnoticias/infomoney/2011/05/06/numero-internautas-nossites-de-compra-coletivas-cresce-30-em-marco.jhtm>, Access: July 29, 2011.

[16] S. Weinschenck, Neuro Web Design: what makes them click?, London: New Riders Press, 2009. 